Acta Theriologica $36(1-2): 153-161,1991$.

PL ISSN $0001-7051$

\title{
Structure, reproductive status and dynamics of the otter population in Byelorussia
}

\author{
Vadim E. SIDOROVICH
}

\begin{abstract}
Sidorovich V. E. 1991. Structure, reproductive status and dynamics of the otter population in Byelorussia. Acta theriol. 36: 153 - 161 .

The study was carried out from $1982-1989$ at seven stations located in various parts of Byelorussia. The stations represented different land-use types. The abundance and structure (spacial, sex, age) of the otter Lutra lutra (Linnaeus, 1758) population and some features of breeding biology (time of birth, female role in reproduction, fecundity) were examined. Mortality of both adult and young animals, together with causes of death, were assessed. The effects of harvest and of man-made modifications to areas (mostly transformation of natural waterbodies and the creation of new water reservoirs) on the structure and breeding of otter populations were studied.

Institute of Zoology, BSSR Academy of Sciences, Scoriny 27, 220733 Minsk, USSR

Key words: population ecology, Lutra lutra, Byelorussia
\end{abstract}

\section{Introduction}

The otter Lutra lutra (Linnaeus, 1758), as a top carnivore, is of great significance in the functioning of aquatic ecosystems. It is also of commercial value. However, at present, the scale of decline in this important species and the reasons for reductions in numbers are insufficiently known (Erlinge 1971, Chanin 1985). Hence, the study of otter reproduction and of population structure and dynamics is of practical importance both for game management and for nature protection. There have been some studies on reproduction and fecundity (Teplov 1953, Erlinge 1967, Vshivtsev 1972, Danilov and Tumanov 1976, Stubbe 1977, Jenkins 1980, Jenkins and Harper 1982), on causes of mortality (Teplov 1960, Danilov and Tumanov 1976, Stubbe 1978), and on density, spacial structure, sex and age composition (Teplov 1953, Erlinge 1971, Vshivtsev 1972, Danilov and Tumanov 1976). However, although the number of such studies is high, the level of information is still limited. Data on demographic parameters and on factors influencing otter population dynamics are scanty. Such factors include harvesting, the structural transformation of natural wetlands, the creation of man-made waterbodies and water pollution. The impact of anthropogenic pollution of waterbodies (Erlinge 1971, Olsson and Sandegren 1983, Chanin 1985, Macdonald and Mason 1988, Skaren 1988) and habitat modifications (Macdonald and Mason 1983, 1985; Reuther 1985) upon the otter has been studied but many questions of this matter are still without answers. The influences of industry upon the state of otter populations are poorly investigated. Yet, according to previous studies (Sidorovich 1988, 1989) it is these latter factors which determine both status and population dynamics of otters in Byelorussia. The present paper concerns these aspects of the otter ecology. 


\section{Materials and methods}

The observations were made at 7 stations in different areas of Byelorussia between 1982 and 1989. The stations differed in the use made of them by man and comprised a system of protected waterbodies (Beresinsky Biosphere Reserve), a system of modified waterbodies where the fauna is protected (Naliboksky Game Reserve), and five systems of waterbodies typical of those used by man for all types of activities including hunting. Accounting for repeated observations, both at and outside the study sites, a total of 4.7 thousand kilometers of waterway was examined. In addition, 54 lakes, 7 reservoirs, the fish ponds of 3 farms and 8 other ponds were examined. The habitat components were assessed according to the method described by Sidorovich (1988). Otter populations were estimated by the method recommended by Teplov (1952) and Ternovsky (1973). By this procedure sex is determined by observations of the relative position on the substrate of faeces to urine (with males the urine is found in front of the faeces while in females the urine is found on top or behind the faeces relative to the hind footprints). The length of the hind footprint is also taken into account. Clearly this procedure requires snow or a suitable soft substrate. Young animals accompanying the female (aged over 3 months) were identified by the same procedure. The number of young in each litter was determined by counting numbers of tracks and by direct observations. Since the probability of animals of the same sex and with similar print size ( $<1 \mathrm{~cm}$ difference) occuring at boundary areas is very low $(p=0.01-0.05)$, the data obtained were used to estimate population densities at the different study sites. From a knowledge of the densities of animals found in different types of waterbody, it was possible approximately to assess otter abundance in the whole of Byelorussia.

Age and sex structure of the populations were assessed

Table 1. Length (in $\mathrm{cm}$ ) of hindfoot prints of otters of different sex and age.

\begin{tabular}{lcc}
\hline Age, year of life & Males & Females \\
\hline 1st & $5.0-5.9$ & $4.0-4.7$ \\
2nd & $6.0-7.8$ & $4.8-6.5$ \\
3rd & $7.9-13.5$ & $6.6-11.9$ \\
\hline
\end{tabular}
as follows. Sex and print size were recorded as described above. Animals could then be aged by reference to the length of the hindprint (see Table 1) based on data collected both by other authors (Teplov 1952, Savitsky and Rodikov 1980) and on observations made using harvested otters, where the length of the hindprint (made on soil or snow) could be related to age determined by canine cementum banding (Klevezal and Kleinenberg 1967, Stephenson 1977). If the hindprint length is close to the size limit for a particular age group then errors in identification may occur. However such errors in ageing usually result in an over- or under-estimate of only $3-5$ months and, being random, were treated as insignificant. Indeed computer simulation of such errors showed that they account up to $2 \%$, or on average, less than $1 \%$. In the present study the age-sex structure of the otter populations was based on 1217 observations.

The age of otters harvested by hunters $(n=73)$ was determined from the degree of fusion of the skull sutures (Stubbe 1969) and tooth band structure (Klevezal and Kleinenberg 1967, Stephenson 1977). The age ratios of harvested adult otters were also used in the estimation of age composition in exploited populations.

Otter reproduction was studied by use of the author's own records and from information from other zoologists and hunters. Embryo number was recorded in 7 pregnant females. The sizes of 42 litters of blind cubs (aged up to 1 month) were noted with sex ratios being determined for 13 of these. Such litters could be found in abandoned beaver lodges which are frequently used as breeding sites by female otters. The sizes of 133 litters (sex composition for 124) accompanying females, (and therefore more than 3 months old), were determined by direct observation or by print counts along tracks and at sites marked with faeces. The proportion of females without young was also noted. A relative increase in this proportion implies an increase in non-breeding females. The ratio of adult to young animals is taken as an index of breeding levels in otter populations.

Mortality of otters during the first year of life $\left(\mathrm{S}_{1}\right)$ was determined from the ratio of numbers of 2 to 1 -year old animals $\left(\mathrm{K}_{2} / \mathrm{K}_{1}\right)$ and from the ratio of the average size of litters less than 1 month old (blind) to the size of litters old enough to accompany the female $\left(K_{3} / K_{4}\right)$. The formula $S_{1}=1-K_{2} / K_{1} \times K_{3} / K_{4}$ is then employed. The mortality of otters during the second and later years of life was estimated by computer simulation based on maximum and minimum life spans and on mortality during the first year of life. Life expectancy of otters 
inhabiting exploited areas was estimated from the ages of harvested animals since hunting (under licence but mostly illegal) is the main cause of mortality in study area. Population growth rate was estimated from data on reproduction, mortality and sex-age structure (Caughley 1977).

For all studied parameters, means (Avg.) and standard deviations (SD) were calculated. On some data coefficients of variation (V) were calculated. The relationships between otter density and habitat variables were examined using Spearman rank correlation $\left(r_{\mathrm{s}}\right.$. Significance in statistical tests was accepted at $p \leq 0.05$.

\section{Results}

\section{Structure of the otter populations}

Otter densities on waterways of different types where the animals are protected are given in Table 2. By comparison (Table 2), densities in areas used by hunters are much lower.

Correlation analysis of the data presented in Table 2 (Sidorovich 1988, 1989) showed that otter population density was determined by the following factors: water level $\left(r_{\mathrm{s}}=0.32-0.47\right.$, $p=0.01-0.05)$, abundance of waterbodies within the floodplain $\left(r_{\mathrm{s}}=0.64, p<0.01\right)$, meanders $\left(r_{\mathrm{s}}=0.58, p<0.01\right)$, flow rate $\left(r_{\mathrm{s}}=0.92-0.96, p<0.01\right)$, number of beaver lodges $\left(r_{s}=0.73-0.78, p<0.01\right)$ and the proportion of rather high, steep, forest and shrub covered banks $\left(r_{\mathrm{s}}=0.42-0.56, p<0.01\right)$. Generally (see Table 2 ) otter population density is

Table 2. Otter densities at streams of different type, expressed as numer of individuals per $10 \mathrm{~km}$ of stream. Averages and standard deviations are given, and followed by the number of examined rivers, or parts of rivers, including repeated examinations (in brackets).

\begin{tabular}{|c|c|c|c|}
\hline Stream type & $\begin{array}{c}\text { Protected } \\
\text { populations }\end{array}$ & $\begin{array}{l}\text { Exploited } \\
\text { populations }\end{array}$ & $\begin{array}{l}\text { Significance } \\
\text { of difference }\end{array}$ \\
\hline $\begin{array}{l}\text { Slow flow rate large and secondary rivers } \\
\text { with averagely or overflown floodplain }\end{array}$ & $2.7 \pm 0.3(22)$ & $2.2 \pm 0.3$ & $\begin{array}{l}t=2.0 \\
p=0.05\end{array}$ \\
\hline $\begin{array}{l}\text { Moderate flow rate large and secondary rivers } \\
\text { with weakly or moderately flooded plain }\end{array}$ & $3.8 \pm 0.3(29)$ & $3.1 \pm 0.3(12)$ & $\begin{array}{l}t=3.6 \\
p<0.001\end{array}$ \\
\hline Slow rate small rivers & $1.7 \pm 0.2(15)$ & $1.0 \pm 0.2$ & $\begin{array}{l}t=4.4 \\
p<0.001\end{array}$ \\
\hline Moderate rate small rivers & $2.9 \pm 0.3(32)$ & $2.0 \pm 0.4(40)$ & $\begin{array}{l}t=6.3 \\
p<0.001\end{array}$ \\
\hline High rate small rivers & $4.0 \pm 0.5$ & $2.7 \pm 0.6(26)$ & $\begin{array}{l}t=4.2 \\
p<0.001\end{array}$ \\
\hline $\begin{array}{l}\text { Old ( } 80 \text { years and older) forest drainage } \\
\text { and other type channels }\end{array}$ & $1.5 \pm 0.2$ & $0.9 \pm 0.2$ & $\begin{array}{l}t=2.2 \\
p=0.002\end{array}$ \\
\hline $\begin{array}{l}\text { Channeled small rivers and other rather flooded channels } \\
\text { of contemporary (recent } 45 \text { years) forest drainage system }\end{array}$ & $1.2 \pm 0.6(24)$ & $0.6 \pm 0.2(19)$ & $\begin{array}{l}t=3.0 \\
p=0.002\end{array}$ \\
\hline $\begin{array}{l}\text { Major rather flooded channels of agricultural } \\
\text { drinage system }\end{array}$ & $0.7 \pm 0.1(18)$ & $0.2 \pm 0.1(29)$ & $\begin{array}{l}t=5.3 \\
p<0.001\end{array}$ \\
\hline
\end{tabular}


significantly lower on channelized water courses than on natural rivers $(t \geq 2.3, p \leq 0.02$; on old forest channels $t=0.9, p>0.1$ ). Features which favour otter populations on channels are associated with beaver activity $\left(r_{\mathrm{s}}=0.82, p<0.01\right)$, water depth $\left(r_{\mathrm{s}}=0.51, r_{\mathrm{s}}=0.51\right.$, $p<0.01)$, the abundance of high, steep, wooded banks $\left(r_{s}=0.77, p<0.01\right)$ and flow rate $\left(r_{\mathrm{s}}=0.32, p=0.03\right)$.

Inland waters such as lakes, reservoirs and ponds are only used by otters during ice-free periods. Their density depends on the number of forest/shrub covered islands $\left(r_{\mathrm{s}}=0.64\right.$, $p<0.01)$, the number of inflowing and outflowing streams $\left(r_{\mathrm{s}}=0.78, p<0.01\right)$, the abundance of relatively high, steep, wooded banks $\left(r_{\mathrm{s}}=0.60, p<0.01\right)$ and beaver constructions $\left(r_{\mathrm{s}}=0.78, p<0.01\right)$. During ice cover food becomes unavailable and the otters leave these waterbodies.

From estimates of population density in waterbodies of different types and with different topographical features, Sidorovich (1989) showed that, in exploited areas, a density of $1-10$ (average 4.3) otters occured per $100 \mathrm{~km}^{2}$, while in protected areas the number is $3-18$ (average 6.9) per $100 \mathrm{~km}^{2}$.

The sex-age structure of protected populations (Table 3 ) is characterized by a rather small (as compared with other mustelids) proportion of first-year (26.5\%) and second-year animals (16.9\%). The sex ratio is almost equal in all age groups with males comparising $52.7 \%$.

In exploited populations the proportion of first-year animals does not exceed that of protected populations (in some cases it is smaller; $t=2.0, p=0.05$ ) but the proportion of second-year individuals (see Table 3 ) is significantly smaller $(t=2.0, p=0.05)$. In exploited populations the proportion of adults to juveniles (Table 3$)$ is greater $(t>2.1, p<0.05)$ but the adults are younger. The mean life span of unprotected otters is 3.5 years with a maximum of

Table 3. Sex and age structure (\%) of otter populations. Means and observed ranges (in brackets) are given.

\begin{tabular}{lcc}
\hline Sex-age group & $\begin{array}{c}\text { Protected } \\
\text { populations } \\
(\mathrm{n}=539)\end{array}$ & $\begin{array}{c}\text { Exploited } \\
\text { populations } \\
(\mathrm{n}=678)\end{array}$ \\
\hline $\begin{array}{c}\text { Young (during 1st year of life) } \\
\text { total }\end{array}$ & $26.5(25.6-27.8)$ & $23.9(21.1-26.7)$ \\
males & $52.4(51.5-53.3)$ & $53.1(52.4-54.0)$ \\
females & $47.6(46.7-48.5)$ & $46.9(46.0-47.6)$ \\
Sub-adult (2nd year of life) & & \\
$\quad$ total & $16.9(15.2-18.2)$ & $11.8(10.4-13.0)$ \\
males & $52.7(50.9-53.1)$ & $48.5(47.5-49.2)$ \\
females & $47.3(46.9-49.1)$ & $51.5(50.8-52.5)$ \\
Adult (3rd year of life and older) & & \\
total & $56.6(56.2-57.0)$ & $64.3(62.9-65.8)$ \\
males & $52.9(52.2-53.5)$ & $39.9(34.9-42.4)$ \\
females & $47.1(46.5-47.8)$ & $60.1(57.6-65.1)$ \\
\hline
\end{tabular}


nearly 10 years $(n=73)$. In exploited regions adults of $3-5$ years old comprise $50 \%$ of the population with $41 \%$ being $6-9$ years old and $9 \%$ being 10 years or more. Males comprise $68 \%$ of the commercial harvest $\left(\chi^{2}=17.7, p<0.01\right)$ and $76 \%$ of the adults killed $\left(\chi^{2}=54.0\right.$, $p<0.01)(\mathrm{n}=183)$. Thus, in exploited populations the normal sex ratio structure is disrupted (see Table 3 ) with a higher proportion of females in the population $\left(\chi^{2}=26-9.0\right.$, $p=0.1-0.003)$.

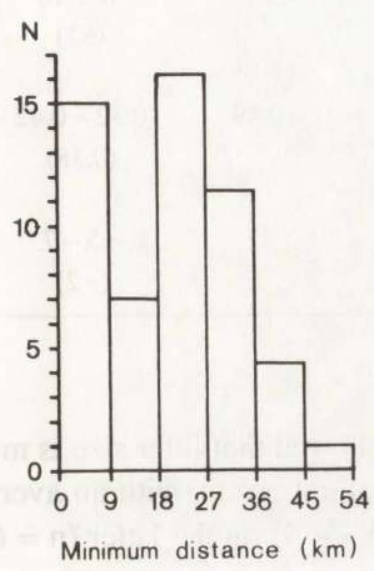

Fïg. 1. Spacial distribution of adults over the territory of hunting grounds. Minimum distance - distance between adult male and female along stream.
The low population density and the artificial sex ratio results in adult males and females often being separated by long distances: $23 \mathrm{~km}$ on average, with a maximum of $54 \mathrm{~km}$ (Fig. 1). In addition, since females have no specific breeding season (Danilov and Tumanov 1976), the potential for breeding is even further reduced.

\section{Otter breeding}

In Byelorussia breeding occurs mainly during April - May and October - November although births do occur in other months (Fig. 2). The number of embryos is $2-4$ (average 2.71) $(n=7)$. Litters less than 1 month old (blind) consist of $1-4$ (average 2.62) cubs $(n=42)$. The sex ratio is approximately equal. Thirteen litters were examined and comprised 18 males and 16 females. The cubs stay in the den until they are $2.5-3$ months old. During this period

a few cubs (no more than $8 \%$ ) die. Litters of over 3 months of age (following the female) consist of $1-4$ (average 2.42) cubs $(n=133)$. The sex ratio is again nearly equal. Of 309 cubs, 161 were males.

Comparisons of fecundity (sizes of litters aged over 3 months) in protected and exploited populations (Table 4) showed the latter to have much higher values $(t=1.4-2.1$, $p=0.05-0.1)$. However, the rate of reproduction decreases in exploited populations due to the high number of non-breeding females (Table 4).

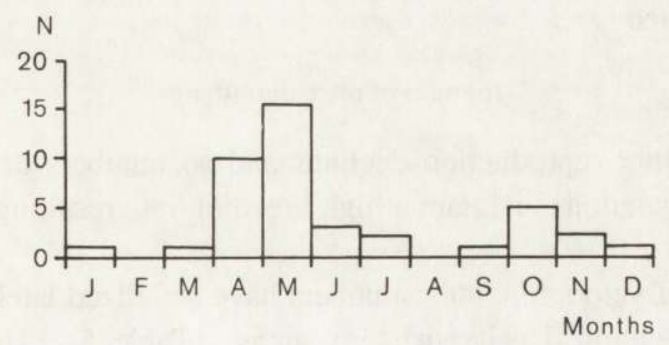

Fig. 2. Seasonal dynamics of otter pup birth in Byelorussia (according to findings of litters with blind pups, $n=42$ ). 
Table 4. Reproductive parameters in otter populations studied.

\begin{tabular}{lcccc}
\hline Parameters & $\mathrm{n}$ & $\begin{array}{c}\text { Beresinsky } \\
\text { Nature Reserve }\end{array}$ & $\begin{array}{c}\text { Naliboksky } \\
\text { Reserve }\end{array}$ & $\begin{array}{c}\text { Hunting } \\
\text { grounds }\end{array}$ \\
\hline $\begin{array}{l}\text { Average litter size (aged over 3 months) } \\
\text { Percentage of adult non-breeding females }\end{array}$ & 133 & 2.24 & 2.30 & 2.53 \\
Ratio of young to adult individuals & 1217 & 0.46 & 0.49 & $\begin{array}{c}0.32-0.42 \\
(0.38)\end{array}$ \\
& & & 27 & $\begin{array}{c}47-75 \\
\text { Increase in numbers, \% }\end{array}$ \\
\end{tabular}

Comparisons of sizes of litters with cubs over 3 months old showed that litter size is much lower on small channelized rivers $(t=2.0, p=0.05)$ than on natural rivers, with an average of 2.1 (range $1-3)$ cubs $(n=18)$ on the former and 2.4 (range $1-4)$ on the latter $(n=67)$.

\section{Mortality in otter populations}

In protected otter populations natural specific mortality of young males and females is almost equal and ranges from 0.30 to 0.40 . In exploited populations mortality amongst the young is $0.52(0.37-0.70)$ being lower in females $(0.47)$ than in males $0.57 \quad(t=2.4$, $p=0.02$ ). Specific mortality in 2 year olds comprises 0.25 in exploited populations.

During this study 389 cases of otter killed were recorded. The main cause of otter mortality was hunting, mostly illegal $(92.5 \%)$. Other deaths were caused by drowning in fish nets (2.8\%), disease $(n=4)$, starvation during periods of ice cover $(n=3)$, road traffic $(n=2)$, killing by hunting $\operatorname{dog}(n=1)$, and poisoning by toxic substances flowing to rivers during industrial accidents $(n=2)$. The young may be killed by dogs (death of cubs from 4 litters) and one litter of 3 cubs aged about 2 months died after their mother was killed by hunters. The latter can be one of the main causes of cubs mortality, since 5 lactating females killed by hunters were additionally recorded.

\section{Dynamics of otter abundance}

In exploited areas otter reproduction declines and so numbers decrease to some extent (Table 4). Protected populations maintain a high breeding rate resulting in a $13-17 \%$ annual growth rate.

Overall, in much of Byelorussia, otter numbers have stabilized lately, as evidenced by the relatively constant population density in study areas (Table 5). However, in south-west Byelorussia numbers have decrease slightly. Sidorovich (1989) estimated a population of nearly 12,000 individuals in the whole of Byelorussia, i. e. $207,600 \mathrm{~km}^{2}$. 


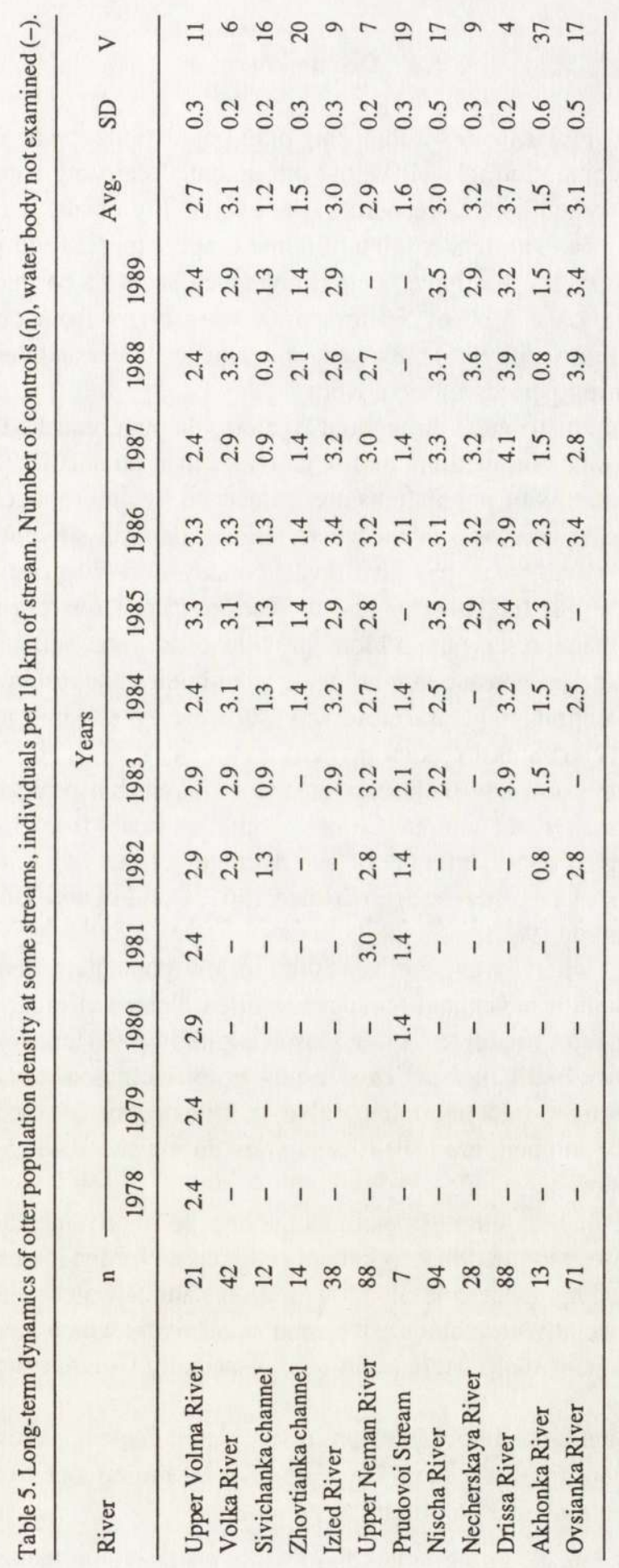




\section{Discussion}

From this study the major factors influencing otter populations can be identified. Excessive hunting reduces the population to well below the potential carrying capacity of the habitat. Food availability, governed by fish resources, the availability of alternative prey and access to open water determines the otters' choice of home range, especially in winter. Decreases in population density on rivers that have been straightened seem to be due to declines in fish resources (Hartle and Lake 1983). Factors preventing otters from occupying man-made reservoirs (including those with fish) are a lack of adequate shelter and den sites and problems of access to water during periods of ice-cover.

At present otters are distributed throughout Byelorussia on a branched spacial pattern with higher popuiation densities on medium and large rivers than on small streams (Table 2). The density and spacial patterns of populations are influenced by anthropogenic modifications to their habitats. Significant decreases occur where large-scale river straightening schemes have been carried out. However, man has also created many new waterways such as drainage channels, reservoirs, ponds for fisheries and recreation, canals for transporting urban water supplies, etc. Man-made reservoirs seldom provide conditions suitable for resident otter populations but the general increase in man-made waterbodies has resulted in some growth of otter numbers. Modifications to natural waterways, however, result in some decline in density and to a disruption of the natural spacial pattern.

In Byelorussia otter cubs may be born at any time of year but peaks of breeding occur in the second halves of spring and autumn. Litter size at birth varies from $1-4$ (mean 2.6 - 2.7) while litters surviving to over 3 months of age average 2.4 cubs $(1-4)$. This is similar to findings in other parts of the otters range (Erlinge 1967, Danilov and Tumanov 1976, Stubbe 1977, Jenkins and Harper 1982).

In exploited areas, where over-hunting results in low population densities and unnatural sex ratios, individual adult males and females are often located at great distances from each other. Since there is no specific reproductive season (Danilov and Tumanov 1976), possibilities for breeding are reduced still further. This results in an increased number of non-breeding females and a decline in reproduction rates (Table 4). This decline is exacerbated by the deaths of young otters whose mothers are killed by hunters during the $1-1.5$ years during which they are dependent upon her.

It has been found that, as otter populations decline, fecundity increases and mortality of young females decreases but these factors cannot compensate for the losses caused by irrational harvest policies. Breeding success is also lowered on natural waterbodies which have been modified by man, especially on medium sized and small rivers which have been straightened. This is due to the resultant sharp decrease in food, especially fish, resources (Hartle and Lake 1983).

Protected otter populations living in nature reserves and game reserves provide the sources for potential recruitment to other areas. They are of great importance to the stabilization and growth of otter populations in Byelorussia.

Acknowledgements: Many thanks are due to Dr Chris Masson, Department of Biology, University of Essex, England for his valuable comments on earlier draft of the paper and corrections of English. 


\section{References}

Caughley G. 1977. Analysis of vertebrate populations. John Wiley and Sons, London: $1-361$.

Chanin P. 1985. The natural history of otters. Croom Helm., London: $1-179$.

Danilov P. I. and Tumanov I. L. 1976. Kunji severo-zapada SSSR. Izdatelstvo Nauka, Leningrad: 193 - 212.

Erlinge S. 1967. Food habits of the fish-otter, Lutra lutra L., in south Swedish habitats. Viltrevy 4: $371-443$.

Erlinge S. 1971. The situation of the otters population in Sweden. Viltrevy 8:379 - 397.

Hortle K. G. and Lake P. S. 1983. Fish of channelized and unchannelized sections of the Bunyip River, Victoria. Austral. J. Mar. and Freshwater Res. 34: 441 - 450.

Jenkins D. 1980. Ecology of otters in northern Scotland. I. Otter (Lutra lutra) breeding and dispersion in midDeeside, Aberdeenshire in 1974 - 79. J. of Animal Ecology 49: 737 - 754.

Jenkins D. and Harper R. J. 1982. Fertility in European otters (Lutra lutra). J. Zool., Lond. 197: 299 - 300.

Klevezal G. A. and Kleinenberg S. E. 1967. Opredelenie vozrasta mlekopitajuščih po sloistym strukturam zubov i kosti. Izdatelstvo Nauka, Moskva: 1 - 144

Macdonald S. M. and Mason C. F. 1983. Some factors influencing the distribution of otters (Lutra lutra). Mammal Rev. 13: $1-10$

Macdonald S. M. and Mason C. F. 1985. Otters, their habitat and conservation in Northeast. Biol. Conserv. 31: $191-210$

Macdonald S. M. and Mason C. F. 1988. Observations on an otter population in decline. Acta theriol. 33: $415-434$.

Olsson M. and Sandegren F. 1983. Is PCB responsible for the decline of the otter in Europe? Proceedings of the III International Otter Colloquium, Strassbourg.

Reuther C. 1985. Die Badeutung der Uferstruktur für den Fischotter (Lutra lutra) und daraus resultierende Anforderungen an die Gewässerpflege. Z. angew. Zool. 72: 93 - 128.

Savitsky B. P. and Rodikov V. I. 1980. Instrukcija po opredeleniju pola i vozrasta vydry pri polevyh issledovanijah. Reprint, Gomel: $1-15$.

Sidorovich V. E. 1988. Ekologičeskij analiz plotnosti naselenija poluvodnyh hiščnikov na malyh vodotokah Belorussii. Zapovedniki Belorussii. Issledovanija, Minsk 12: 123 - 126.

Sidorovich V. E. 1989. Tipologija vodojomov kak mesto obitanij poluvodnyh hiščnikov, plotnost i čislennost ih populacij v Belorussii. Deponirovano v VINITI 05.II.88, Minsk, n7935-B88: 1 - 54. [Unpubl. report]

Skaren U. 1988. Chlorinated hydrocarbons, PCBs and cesium isotopes in otters (Lutra lutra) from Central Finland. Ann. zool. fenn. 25: $271-276$.

Stephenson A. B. 1977. Age determination and morfological variation of Ontario otters. Can. S. Zool. 55: $1577-1583$.

Stubbe M. 1969. Zur Biologie und zum Schutz des Fischotters Lutra lutra L. Arch. Naturschutz und Landschaftsforsch. 9: $315-324$.

Stubbe M. 1977. Der Fischotter Lutra lutra (L., 1758) in der DDR. Zool. Ans. 3 - 4: 265 - 285.

Stubbe M. 1978. Der Fischotter Lutra lutra (L., 1758) in den mittleren Bezirken der DDR. Hercynia 15: $77-105$.

Teplov V.P. 1952. Količestvennyj učiot vydry, sobolja, kunicy i melkih predstavitelej semejstva Kunjih. Metody učiota čislennosti i geografičeskogo raspredelenija nazemnyh pozvonočnyh zivotnyh. Izdatelstvo Nauka, Moskva: $165-172$.

Teplov V. P. 1953. Riečnaja vydra v rajone Pečorsko-Ilyčskogo zapovednika. Bjull. Mosk. Obšč. Ispyt. Prirody. Otd. Biol. 58, 6: 7 - 16 .

Teplov V. P. 1960. Dinamika čislennosti i godovye izmenenija v ekologii promyslovyh zivotnyh Pečorskoj tajgi. Trudy Pečorsko-Ilyčeskogo zapovednika 8.

Ternovsky D. V. 1973. Količestvennyj učot vydry i norki. Trudy Okskogo zapovednika 9: 144 - 161.

Vshivtsev B. I. 1972. Vydra Sahalina. Izdatelstvo Nauka, Novosibirsk: 1- 106.

Received 6 September 1989, accepted 15 July 1991. 